\title{
Fertility measures in Polish Black-and-White cattle. 2. Genetic parameters of interval measures*
}

\author{
W. Jagusiak \\ Agricultural University of Cracow, Department of Genetics and Animal Breeding \\ Mickiewicza 24/28, 30-059 Kraków, Poland
}

(Received 3 September 2004; revised version 13 May 2005; accepted 4 August 2005)

\begin{abstract}
Genetic parameters of service period, calving interval, days open, days to first service and days of pregnancy were estimated. Data were records of 42,283 cows. Heritabilities of all traits in first parity were low and ranged from 0.044 for calving interval to 0.092 for service period. Heritabilities of all intervals decreased in consecutive parities, and in the third parity were close to zero for days open and days to first service. The highest genetic correlation was found between calving interval and days open (0.99), days to first service and days open (0.74), and days to first service and calving interval $(0.72)$. Service period was highly correlated genetically with age at first service $(0.72)$, age at conception (0.90) and age at calving (0.90). The genetic correlation between days open and age at first insemination was 0.44 . Genetic correlations of fertility traits between parities were highest when estimated for first and second parity, and ranged from 0.92 to 0.99 .
\end{abstract}

KEY WORDS: dairy cattle, fertility, genetic parameters, linear animal model

\section{INTRODUCTION}

The fertility measures in dairy cattle can be classified into interval measures such as service period, calving interval, days open, days to first service, and score measures described in the previous paper (Jagusiak, 2005). Recently, the dairy cattle breeding program in Poland has been focused on increasing income per cow, rather than decreasing production costs and the official selection index

\footnotetext{
" Supported by the State Committee for Scientific Research, Grant No. 2 P06D 03827

Corresponding author: e-mail: rzjagusi@cyf-kr.edu.pl
} 
consists of breeding values for production traits only (http://www.kchz.agro.pl/ programy.htm). Interval fertility traits strongly influence the economics of cattle breeding; very long calving intervals increase production expenses by decreasing cow productivity and number of progeny. The calving interval consists of two periods: days open (from calving to conception) and gestation length. Very low variability of gestation length implies a large impact of days open on the calving interval. The number of days open is the sum of two shorter intervals: days to first service (from calving to first insemination) and service period (from first to last insemination). Both mentioned components are strongly influenced by management (oestrus detection, feeding, etc.)

Numerous European countries practice evaluation of sire breeding values for daughter fertility measures. In Canada, the interval from calving to first service, and the non-return rate to $56^{\text {th }}$ day are evaluated using a multitrait animal model (Van Doormal et al., 2004). Joint evaluation of fertility traits including service period, days open and days to first service, is practiced in four Nordic countries: Sweden, Denmark, Norway and Finland. In Denmark, days to first service and service period are used; in Finland, days open are used (Fogh et al., 2003). In Switzerland (Schnyder and Stricker, 2002) and the Netherlands (https://www.crdelta.nl/english/index.htm) the interval from calving to first insemination is a measure of female fertility. In Canada, Denmark, Finland, Switzerland and the Netherlands, sire breeding value estimated for interval fertility measures is often combined with score measures in a common fertility index, which is next included in a total merit index (Misenberger et al., 1997; http://www-interbull.slu.se). Recently, studies on joint evaluation of fertility traits and longevity have been presented by Olori et al. (2003).

Heritabilities of interval fertility measures reported in the literature are in general consistently low. The typical estimations published by Fogh et al. (2003) were 0.02 for heifer service period, 0.04 for days to first service, and 0.04 for days open. Heritabilities of interval measures in later lactations were published in a few papers (Jansen et al., 1987, Weller and Ezra, 2004). Estimations of variance components in second and third lactations could be biased because of previous culling; however, the restricted maximum likelihood procedure with a full relationship matrix accounts for selection if information on selection decisions is included in the data (Meyer, 1983; Meyer and Thompson, 1984).

The genetic parameters of fertility measures are needed to estimate breeding values of cattle and to construct selection indexes. Recently, estimations of genetic parameters in Polish Black-and-White cattle have not been available. The purpose of this paper was to estimate the heritabilities of interval measures of fertility in Polish Black-and-White cattle in first and later parities, as well as genetic and phenotypic correlations between them. 


\section{MATERIAL AND METHODS}

Data were 763,073 records of Polish Black-and-White cows born between 1996 and 2000. After formal edits a file with 289,500 records of cows was created. From the total 2018 sires with 20 or more daughter records, 1018 bulls were randomly chosen (described in detail in the previous paper). The final data set contained 42,283 records of cows. The cows calved for the first time in 785 herds and were allocated in 2217 herd-year-season and 1657 herd-year subclasses. The following fertility measures were calculated for each cow in the first three parities:

- service period, days (interval from first insemination to conception),

- days of pregnancy, days (interval from conception to calving),

- days to first service, days (interval from calving to first service).

- days open, days (interval from calving to conception),

- calving interval, days (interval from calving to the next calving).

The service period and pregnancy days were calculated in the first, second, and third parities for $42,283,25,013$ and 11,021 cows, respectively, whereas days to first service, days open and calving interval could be computed for 25,013, 11,021 and 5,834 cows, respectively.

(Co)variance components of the fertility traits were estimated by restricted maximum likelihood (REML) (Misztal and Perez-Enciso, 1993) with a relationship matrix, based on the following linear model:

$$
\mathbf{y}=\mathbf{X b}+\mathbf{Z Q g}+\mathbf{Z u}+\mathbf{e}
$$

where $\mathbf{y}$ is the vector of observations, $\mathbf{g}$ is the vector of fixed effects of genetic groups, $\mathbf{b}$ is the vector of fixed effects of herd-year of calving and month of calving, $\mathbf{u}$ is the vector of additive animal genetic effects, $\mathbf{e}$ is the vector of residual error, and $\mathbf{X}, \mathbf{Z}$ and $\mathbf{Q}$ are coincidence matrices. Matrix $\mathbf{G}=\mathbf{A}^{-1} \otimes \mathbf{G}_{0}$, where $\mathbf{A}^{-1}$ is a numerator relationship matrix and $\mathbf{G}_{0}$ a genetic (co)variance matrix between traits. Matrix $\mathbf{R}=\mathbf{I} \otimes \mathbf{R}_{0}$, where $\mathbf{R}_{\mathbf{0}}$ is a residual (co)variance matrix between traits and $\otimes$ is the Kronecker product.

The linear models used for fertility measures in the second and third parities also contained fixed regression for the first calving interval.

Genetic groups were created according to the rules given by Westell et al. (1988). Animals with unknown parents were assigned to genetic groups by birth year and percentage of Holstein-Friesian genes. Five groups for male and eight for female unknown parents were formed.

Variance components for service period, days of pregnancy, days open, calving interval and days to first service in the first, second and third parities were estimated using a single-trait animal model. In the next step a multitrait animal model was 
applied to estimate (co)variances between first-parity-interval fertility measures as well as (co)variances between measures in different parities. Genetic and phenotypic correlations were computed based on estimated (co)variances.

\section{RESULTS}

Average service periods and pregnancy days, by percentage of HF genes, are shown in Table 1. Differences between genetic groups were in general small. The service period was shortest for pure Black-and-White cows (25.6 days) and longest (about 29 days) for cows with an average percentage of HF genes. Pure HolsteinFriesians had a service period one day longer on average than pure Black-andWhite cows. The number of pregnancy days was 278 on average, and although differences between genetic groups were quite small the gestation length decreased with increasing percentage of HF genes; pure Holstein-Friesians calved on average one day earlier than pure Black-and-White cows.

TABLE 1

Means and standard deviations for service period and pregnancy days in first parity, by percentage of HF genes

\begin{tabular}{|c|c|c|c|c|c|}
\hline \multirow{2}{*}{ Percentage of HF genes } & \multirow{2}{*}{$\mathrm{n}$} & \multicolumn{2}{|c|}{ Service period } & \multicolumn{2}{|c|}{ Pregnancy days } \\
\hline & & $\overline{\mathrm{x}}$ & $\mathrm{SD}$ & $\overline{\mathrm{x}}$ & SD \\
\hline 0 & 1,058 & 25.6 & 59.9 & 278.6 & 5.7 \\
\hline $0.1-25$ & 25,625 & 26.7 & 52.3 & 278.2 & 5.6 \\
\hline $25.1-50$ & 12,478 & 29.3 & 56.7 & 277.7 & 5.6 \\
\hline $50.1-75$ & 1,732 & 28.9 & 52.6 & 277.5 & 5.7 \\
\hline $75.1-100$ & 1,390 & 26.5 & 50.7 & 277.8 & 5.6 \\
\hline Total & 42,283 & 27.5 & 53.8 & 278.0 & 5.6 \\
\hline
\end{tabular}

TABLE 2

Means and standard deviations for days open, calving interval and days to first service in first parity, by percentage of HF genes

\begin{tabular}{|c|c|c|c|c|c|c|c|}
\hline \multirow{2}{*}{ Percentage of HF genes } & \multirow[t]{2}{*}{$\mathrm{n}$} & \multicolumn{2}{|c|}{ Days open } & \multicolumn{2}{|c|}{ Calving interval } & \multicolumn{2}{|c|}{$\begin{array}{c}\text { Days to first } \\
\text { service }\end{array}$} \\
\hline & & $\overline{\mathrm{x}}$ & SD & $\overline{\mathrm{x}}$ & SD & $\bar{x}$ & SD \\
\hline 0 & 458 & 139.7 & 88.6 & 417.2 & 86.4 & 83.3 & 35.3 \\
\hline $0.1-25$ & 14,499 & 133.1 & 76.2 & 411.1 & 76.8 & 80.3 & 34.3 \\
\hline $25.1-50$ & 8,413 & 129.7 & 76.8 & 406.9 & 77.1 & 77.3 & 35.6 \\
\hline $50.1-75$ & 942 & 130.1 & 80.6 & 406.7 & 80.8 & 75.4 & 36.1 \\
\hline $75.1-100$ & 701 & 139.8 & 83.5 & 417.0 & 83.3 & 87.6 & 42.4 \\
\hline Total & 25,013 & 132.1 & 77.1 & 409.8 & 77.4 & 79.3 & 35.2 \\
\hline
\end{tabular}


Days open, calving interval and days to first service were largest for pure Blackand-white cows and pure Holsetin-Friesians (Table 2). The shortest intervals were obtained for genetic groups with a medium percentage of HF genes. The smallest days open (129.7) was found for cows with $25.1-30 \%$ HF; the shortest calving interval (75.4) and a smaller number of days to first service were found for cows with $50.1-75 \%$ HF genes.

Heritabilities of all traits in the first parity were low and ranged from 0.044 for calving interval to 0.092 for service period (Table 3). Heritabilities of days to

TABLE 3

Heritabilities of fertility traits in first $\left(\mathrm{h}_{1}{ }^{2}\right)$, second $\left(\mathrm{h}_{2}{ }^{2}\right)$ and third $\left(\mathrm{h}_{3}{ }^{2}\right)$ parities (standard errors of heritabilities in brackets)

\begin{tabular}{llccc}
\hline Traits & & $\mathrm{h}_{1}{ }^{2}$ & $\mathrm{~h}_{2}{ }^{2}$ & $\mathrm{~h}_{3}{ }^{2}$ \\
\cline { 1 - 2 } Service period & $0.092(0.038)$ & $0.086(0.041)$ & $0.054(0.035)$ \\
Days of pregnancy & & $0.074(0.004)$ & $0.071(0.004)$ & $0.062(0.003)$ \\
Days open & & $0.051(0.008)$ & $0.045(0.007)$ & $0.043(0.007)$ \\
Calving interval & $0.044(0.009)$ & $0.041(0.009)$ & $0.002(0.005)$ \\
Days to first service & $0.061(0.011)$ & $0.053(0.010)$ & $0.003(0.008)$ \\
\hline
\end{tabular}

first service and days open were similar ( 0.061 and 0.051 , respectively), whereas the heritability of pregnancy days was slightly higher and amounted to 0.074 . Heritabilities of all intervals decreased in consecutive parities, and in the third parity were close to zero for days open and days to first service. Higher heritabilties for days of pregnancy $(0.062)$ and service period (0.054) were found in the third parity.

Genetic and phenotypic correlations among reproductive measures in the first parity are shown in Table 4 . The highest correlation was found between calving

TABLE 4

Genetic (above diagonal) and phenotypic (below diagonal) correlations of interval fertility measures in first parity

\begin{tabular}{llccccc}
\hline No. & Traits & 1 & 2 & 3 & 4 & 5 \\
\hline 1 & Service period & & 0.26 & 0.32 & 0.35 & 0.09 \\
2 & Days of pregnancy & 0.04 & & -0.02 & 0.07 & -0.05 \\
3 & Days open & 0.03 & 0.00 & & 0.99 & 0.74 \\
4 & Calving interval & 0.04 & 0.01 & 0.99 & & 0.72 \\
5 & Days to first service & 0.01 & -0.02 & 0.39 & 0.39 & \\
\hline
\end{tabular}

estimated SE for $r_{g}$ ranged from 0.07 to 0.25

interval and days open (0.99). Days to first service was highly genetically correlated with days open (0.74) and calving interval (0.72). Moderate genetic correlations 
were obtained for service period with days open $(0.32)$ and with calving interval (0.35). Phenotypic correlations except for the correlation between calving interval and days open (0.99) were moderate or low. The phenotypic correlation between days to first service and days open was 0.39 , and between days to first service and calving interval was 0.39 . All remaining correlations were close to zero.

A large and positive genetic correlation was found between service period and age at first service (0.72) (Table 5). Service period was also correlated with

TABLE 5

Genetic $\left(r_{g}\right)$ and phenotypic $\left(r_{p}\right)$ correlations of interval fertility measures in first parity and heifer fertility traits

\begin{tabular}{|c|c|c|c|c|c|c|}
\hline \multirow{2}{*}{ Traits } & \multicolumn{2}{|c|}{ Age first service } & \multicolumn{2}{|c|}{ Age at conception } & \multicolumn{2}{|c|}{ Age at calving } \\
\hline & $\mathrm{r}_{\mathrm{g}}$ & $r_{p}$ & $r_{g}$ & $r_{p}$ & $r_{g}$ & $r_{p}$ \\
\hline Service period & 0.72 & 0.54 & 0.90 & 0.64 & 0.90 & 0.53 \\
\hline Days of pregnancy & 0.20 & 0.04 & 0.30 & 0.06 & 0.23 & 0.12 \\
\hline Days open & 0.44 & 0.03 & 0.32 & 0.06 & 0.15 & 0.04 \\
\hline Calving intervals & 0.30 & 0.03 & 0.34 & 0.06 & 0.12 & 0.04 \\
\hline Days to first service & 0.21 & 0.06 & 0.23 & 0.06 & 0.18 & 0.06 \\
\hline
\end{tabular}

estimated SE for $\mathrm{r}_{\mathrm{g}}$ ranged from 0.11 to 0.24

age at conception $(0.90)$ and age at calving $(0.90)$. Other intervals were moderately genetically correlated with age at first service, age at conception and age at calving; the correlation between days open and age at first insemination was 0.44 , and all remaining correlations were less than 0.35 . Phenotypic correlations were close to zero except for the correlations of service period, which ranged from 0.53 with age at calving to 0.64 with age at conception.

Genetic correlations of fertility traits between parities were highest when estimated for first and second parities and ranged from 0.92 to 0.99 (Table 6).

TABLE 6

Genetic $\left(\mathrm{r}_{\mathrm{g}}\right)$ and phenotypic $\left(\mathrm{r}_{\mathrm{p}}\right)$ correlations of fertility traits between parities

\begin{tabular}{|c|c|c|c|c|c|c|}
\hline \multirow{3}{*}{ Traits } & & & \multicolumn{2}{|c|}{ Parities } & & \\
\hline & \multicolumn{2}{|c|}{ I and II } & \multicolumn{2}{|c|}{ I and III } & \multicolumn{2}{|c|}{ II and III } \\
\hline & $r_{g}$ & $r_{p}$ & $r_{g}$ & $r_{p}$ & $r_{g}$ & $r_{p}$ \\
\hline Days open & 0.99 & 0.08 & 0.47 & 0.01 & 0.34 & 0.08 \\
\hline Calving interval & 0.99 & 0.08 & 0.46 & 0.02 & 0.34 & 0.09 \\
\hline Days to first service & 0.96 & 0.18 & 0.56 & 0.09 & 0.77 & 0.13 \\
\hline Service period & 0.96 & -0.28 & 0.44 & -0.15 & 0.92 & 0.08 \\
\hline Days of pregnancy & 0.92 & 0.17 & 0.94 & 0.22 & 0.91 & 0.21 \\
\hline
\end{tabular}

estimated SE for $r_{g}$ ranged from 0.18 to 0.38 
The lowest correlations were found for days open and calving interval between the second and third parities. Correlations for days to first service and service period were higher between consecutive parities than between the first and third parities. Days of pregnancy was highly correlated genetically for all three parities. Phenotypic correlations between parities were in general low or close to zero. Moderate negative correlations were obtained for service periods between the first and remaining lactations.

\section{DISCUSSION}

The calving interval consists of two subintervals: days of pregnancy and days open. The genetic and phenotypic variation of gestation length is quite small and does not depend on management; therefore the number of days open is the main factor affecting the calving interval. The most efficient cows should calve annually, but a short calving interval implies short days open and in consequence a lower yield and shorter lactations. Marti and Funk (1994) reported an antagonistic relationship between days open and lactation yield. The regression coefficients of days open on milk production indicated 1.1 to 1.3 more days open for each $100 \mathrm{~kg}$ more milk. Makuza and McDaniel (1996) found a positive correlation between lactation yield and previous days open even after adjustment for previous milk. They suggested that the lactation records used for cow and sire breeding value estimation should be adjusted for previous days open because selection only for milk yields is likely to decrease fertility.

The heritabilities of calving interval reported in other papers ranged from 0.01 (Pryce et al., 2001) to 0.086 (Veerkamp et al., 2001). Olori et al. (2003) published an estimate of 0.04 , what was similar to the heritability in Polish Black-andWhite cattle. Pryce et al. (2002) and Wall et al. (2003) obtained slightly smaller heritabilities ( 0.025 and 0.033 , respectively). Heritabilities for days open have ranged from 0.03 (Abdallah and McDaniel, 2000) to 0.066 (Veerkamp et al., 2001), not significantly differing from the estimate published in this paper.

The number of days open consists of the number of days to first service and the service period. In modern dairy cows the interval between calving and first heat is 10 to 20 days longer than a 30 years ago, and the percentage of anoestrus cows at the start of the breeding season can be very large (up to 38\%) in high-producing herds (Lucy, 2001). The negative energy balance is the reason for delay in the first ovulation (Bauman and Currie, 1980). A long interval between calving and first service decreases the lifetime performance of the cow, and must not be neglected by breeders. Berry et al. (2003) estimated the lowest heritability of days to first service (0.02), whereas Veerkamp et al. (2001) and Royal et al. (2002) reported estimates closer to those published in this paper ( 0.07 and 0.11 , respectively). Higher heritabilities $(0.16)$ were 
estimated by Veerkamp et al. (2001) for the interval from calving to first luteal activity in 713 first-lactation cows from experimental dairy herds in the Netherlands, and by Pryce et al. (2001) for days to first heat (0.18). The heritability of service period in our study (0.092) was higher than the estimates of Janson (1980) and Berry et al. (2003), 0.017 and 0.01 , respectively.

Wall et al. (2003) obtained a high genetic correlation between calving interval and days to first service (0.67), similar to our estimates (0.072). The service period is part of days open and the calving interval; therefore the service period is moderately correlated with both traits ( 0.32 and 0.35 , respectively). The very high genetic and phenotypic correlation between days open and calving interval can be explained by the very small variation of number of pregnancy days, which is the other part of the calving interval. The correlations between interval fertility measures and age at first service, age at conception and age at calving were in general positive and moderate. The high correlation between service period and three heifer fertility traits indicate that cows having earlier first-time insemination need a shorter service period, which implies fewer services per conception.

The genetic correlations between all intervals for first and second parities were very large (above 0.99); other correlations (except for days open) were smaller. There are a few studies on correlations between fertility traits in subsequent parities. Jansen et al. (1987) estimated genetic correlations for days to first service between the first three parities; they obtained a higher correlation between second and third parities $(0.89)$ than between first and second parities $(0.80)$, the and lowest (0.78) between first and third parities. Weller and Ezra (2004) estimated the correlations for the inverse of the number of inseminations to conception in percent; they obtained large genetic correlations between all parities, but the largest correlation was between first and third parities (0.86). In our study the correlations between first and second parities were highest for all traits except gestation length. Phenotypic correlations were for all traits small and positive except for service period. Mulitrait animal model approach allows treating measures in consecutive parities as separate traits with different heritabilities. The genetic and environmental correlations for traits between parities can be positive or negative. Small negative phenotypic correlations for service periods between parities can be explained by high and negative environmental correlations.

\section{CONCLUSIONS}

Heritabilities of service period, days of pregnancy, days open, calving interval and days to first service in first parity were low and similar to these published in the literature. Heritabilities of all measures decreased in consecutive parities. 
The genetic correlations between fertility measures (except number of days of pregnancy) were high or moderate. The phenotypic correlations for interval fertility measures between parities were low, while genetic correlations were large only between first and second parities. Estimated heritabilities of interval fertility measures were in general low, but sufficient for estimation of sire breeding values that can be used to construct an overall fertility index.

\section{REFERENCES}

Abdallah J.M., McDaniel B.T., 2000. Genetic parameters and trends of milk, fat, days open, and body weight after calving in North Carolina experimental herds. J. Dairy Sci. 83, 1364-1370

Bauman D.E., Currie W.B., 1980., Partitioning of nutrients during pregnancy and lactation: a review of mechanisms involving homeostatsis and homeorhesis. J. Dairy Sci. 63, 1514-1529

Berry D.P., Buckley F., Dillon P., Evans R.D., Rath M., Veerkamp R.F., 2003. Genetic relationships among body condition score, body weight, milk yield, and fertility in dairy cows. J. Dairy Sci. 86, 2193-2204

Fogh A., Roth A., Maagaard Pedersen O., Eriksson J.-Å., Juga J., Toivonen M., Ranberg I.M.A., Steine T., Sander Nielsen U., Pedersen Aamand G., 2003. Joint Nordic genetic evaluation for fertlity traits. Proceedings of the Interbull Congress. Rome (Italy). Interbull Bull. No. 31, 52-55.

Jagusiak W., 2005. Fertility measures in Polish Black-and-White cattle. 1. Genetic parameters of heifer fertility traits. J. Anim. Feed Sci. 14, ...-...

Jansen J., Van Der Werf J., De Boer W., 1987. Genetic relationships between fertility traits for dairy cows in different parities. Livest. Prod. Sci. 17, 337-349

Janson L. 1980., Studies on fertility in Swedish dairy cattle. II. Genetic Prameters.Acta Agr. Scand. $40,427-436$

Lucy M.C., 2001. Reproductive loss in high-producing dairy cattle: where will it end? J. Dairy Sci. $84,1277-1293$

Makuza S.M., McDaniel B.T., 1996. Effects of days dry, previous days open, and current days open on milk yields of cows in Zimbabwe and North Carolina. J. Dairy Sci. 79, 702-709

Marti C.F., Funk D.A., 1994. Relationship between production and days open at different levels of herd production. J. Dairy Sci. 77, 1682-1690

Meyer K., 1983. Maximum likelihood procedures for estimating genetic parameters for later lactations in dairy cattle. J. Dairy Sci. 66, 1988-1997

Meyer K., Thompson R., 1984. Bias in variance and covariance component estimators due to selection on a correlated trait. Z. Tierz. Züchtbiol. 101, 33-50

Miesenberger J., Sölkner J., Essl A., 1997. In: Proceedings of the International Workshop on Genetic Improvement of Functional Traits in Cattle; Fertility and Reproduction. Grub (Germany). Interbull Bull. No. 18, 78-84

Misztal I., Perez-Enciso M., 1993. Sparse matrix inversion for restricted maximum likelihood estimation of varince componenets by expectation-maximization. J. Dairy Sci. 76, 1479-1483

Olori V.E., Pool M.H., Calus M.P.L., Cromie A.R., Veerkamp R.F., 2003. Joint evaluation of survival and fertility in dairy cattle with a linear model. Proceedings of the Interbull Congress. Beltsville (USA). Interbull Bull. No. 30, 20-24

Pryce J.E., Coffey M.P., Brotherstone S.H.J. Woolliams A., 2002. Genetic relationships between calving interval and body condition score conditional on milk yield J. Dairy Sci. 85, 1590-1595 
Pryce J.E., Coffey M.P, Simm G., 2001. The relationship between body condition score and reproductive performance. J. Dairy Sci. 84, 1508-1515

Royal, M.D., Flint A.P.F., Woolliams J.A., 2002. Genetic and phenotypic relationships among endocrine and traditional. fertility traits and production traits in holstein-friesian dairy cows. J. Dairy Sci. 85, 958-967

Schnyder U., Stricker C., 2002. Genetic evaluation for female fertility in Switzerland. Proceedings of the Interbull Congress. Interlaken (Switzerland). Interbull Bull. No. 29, 138-141

Van Doormaal B.J., Kistemaker G., Fatehi J., Miglior F., Jamrozik J, Schaeffer L.R., 2004. Genetic evaluation of female fertility in Canadian dairy breeds. Proceedings of the Interbull Congress. Sousse (Tunisia). Interbull Bull. No. 32, 86-89

Veerkamp R.F., Koenen E.P.C., De Jong G., 2001. Genetic correlations among body condition score, yield, and fertility in first-parity cows estimated by random regression models. J. Dairy Sci. 84, 2327-2335

Wall E., Brotherstone S., Woolliams J.A., Banos G., Coffey M.P., 2003. Genetic Evaluation of Fertility Using Direct and Correlated Traits. J. Dairy Sci. 86, 4093-4102

Weller J.I., Ezra E., 2004. Genetic analysis of the Israeli Holstein dairy cattle population for production and nonproduction traits with a multitrait animal model. J. Dairy Sci. 87, 15191527

Westell R.A., Quaas R.L., Van Vleck L.D., 1988. Genetic groups in animal model. J. Dairy Sci. 71, $1310-1320$

\section{STRESZCZENIE}

Cechy płodności w polskiej populacji bydla czarno-białego. 2. Parametry genetyczne przestoju poporodowego, długości ciąży oraz okresu usługi, między ocieleniowego i między ciążowego

Oszacowano odziedziczalności i korelacje genetyczne oraz fenotypowe dla następujących cech płodności: okres usługi (odstęp od pierwszego do skutecznego zabiegu inseminacji) przed pierwsza, drugą i trzecią ciążą oraz okres między ocieleniowy, przestój poporodowy (odstęp od ocielenia do pierwszego zabiegu inseminacyjnego), okres między ciążowy (odstęp od ocielenia do skutecznego zabiegu inseminacyjnego) po pierwszym, drugim i trzecim ocieleniu. Do obliczeń wykorzystano zbiór obejmujący daty unasienień i ocieleń 42283 krów. Parametry genetyczne oszacowano przy pomocy metody największej wiarogodności z ograniczeniami (REML). Odziedziczalności wszystkich cech były niskie i wahały się od 0,044 dla okresu miedzy ocieleniowego do 0,092 dla okresu usługi. Odziedziczalności wszystkich okresów malały w kolejnych cyklach produkcyjnych i po zakończeniu drugiej laktacji były bliskie zeru dla okresów od ocielenia do pierwszej inseminacji oraz od ocielenia do skutecznego zabiegu inseminacyjnego. Najwyższą korelacje genetyczną stwierdzono pomiędzy okresem między ocieleniowym i okresem od ocielenia do skutecznej inseminacji $(0,99)$. Korelacja genetyczna między okresem od ocielenia do pierwszego zabiegu inseminacyjnego i okresem ocielenia do inseminacji skutecznej wynosiła 0,74 , a korelacja między okresem od ocielenia do pierwszego zabiegu inseminacyjnego i odstępem między ocieleniowym 0,72 . Okres usługi był wysoce skorelowany genetycznie $\mathrm{z}$ wiekiem pierwszego zabiegu inseminacyjnego $(0,72)$, wiekiem pierwszego zacielenia $(0,90)$ i wiekiem pierwszego ocielenia $(0,90)$. Korelacja genetyczna pomiędzy okresem od ocielenia do skutecznej inseminacji i wiekiem pierwszej inseminacji wynosiła 0,44 . 